NBER WORKING PAPERS SERIES

THE INTERGENERATIONAL MOBILITY OF IMMIGRANTS

George J. Borjas

Working Paper No. 3972

\author{
NATIONAL BUREAU OF ECONOMIC RESEARCH \\ 1050 Massachusetts Avenue \\ Cambridge, MA 02138 \\ January 1992
}

This paper was presented at the May 1990 conference honoring Jacob Mincer's contributions to labor economics. This paper is part of NBER's research program in Labor Studies. Any opinions expressed are those of the author and not those of the National Bureau of Economic Research. 
NBER Working Paper \#3972

January 1992

\title{
THE INTERGENERATIONAL MOBILITY OF IMMIGRANTS
}

\begin{abstract}
This paper analyzes the intergenerational mobility of immigrants. Using the 1940-1970 Censuses, the study reveals an important link between the earnings of immigrants and the earnings of their American-born children. Although there is some regression towards the mean, the earnings of second-generation Americans are strongly affected by variables describing economic conditions in the source countries of their parents. Current immigration policy, therefore, determines not only how immigrants perform in the labor market, but also determines tomorrow's differences in the labor market experiences of American-bom ethnic groups.
\end{abstract}

George J. Borjas

Department of Economics, 0508

University of Califomia,

San Diego

9500 Gilman Drive

La Jolla, CA 92093

and NBER 
THE INTERGENERATIONAL MOBILITY OF IMMIGRANTS

George J. Borjas*

\section{Introduction}

In $1970,4.8$ percent of the population was foreign-born, and 11.8 percent was native-born with foreign parentage (U.S. Bureau of the Census, 1975, p. 116). The economic impact of immigration depends both on how immigrants adapt to the labor market and on the adjustment process experienced by their offspring. The traditional perception of this intergenerational adjustment is vividly depicted by the melting pot metaphor: over the course of two or three generations, immigrants are transformed from a collection of diverse national origin groups into a homogeneous native population. I Beginning with Glazer and Moynihan (1963), modern sociological research argues that this metaphor does not correctly portray the ethnic experience in the United States. These studies instead suggest that many of the cultural and economic differences among immigrant groups are transmitted to their children, so that the heterogeneity found among today's imaigrants becomes the heterogeneity found among tomorrow's ethnic groups.

In contrast to the voluminous literature analyzing the economic impact of immigrants, little is known about the labor market performance of their American-born children. ${ }^{2}$ The studies of Carliner (1980) and Chiswick (1977) compare the earnings of immigrants with those of second- and thirdgeneration Americans using the 1970 Census cross-section. Both studies find that the earnings of second-generation workers are larger than those of the first and third generations. Although this is an interesting and provocative fact, existing research ignores the relationship between the national origin differentials found among immigrants and the differences 
found among the ethnic groups that make up subsequent generations.

Despite the relative disinterest in the economic mobility experienced by immigrant households, a growing literature attempts to model intergenerational mobility in the context of dynastic households that care about the welfare of their children, and that transfer funds to and make human capital investments in their offspring (Becker, 1981; Becker and Tomes, 1986; Becker and Barro, 1988), ${ }^{3}$ In addition, a number of empirical studies reveal that the relationship between the earnings of fathers and sons exhibits substantial regression towards the mean across generations."

This paper analyzes the intergenerational mobility experienced by immigrants in the context of an economic model of immigration. As long as skills are partly transferable across generations, the type of selection that characterizes the skill composition of the lmmigrant flow will be reflected in their children. Thus the source-country characteristics that determine national-origin wage differentials (Borjas, 1987) should also play a role in determining the wages of second-generation ethnic Americans.

The empirical analysis uses the Public Use Samples of the decennial Censuses available between 1940 and 1970 . The evidence indicates that although there is some regression towards the mean, the average earnings of a second-generation ethnic group are strongly influenced by the earnings of the corresponding first-generation national origin group. In addition, the data are consistent with the theoretical implication that source country characteristics are an important determinant of the earnings of both firstand second-generation Americans. 


\section{Eramework}

First-generation workers reside in country $x$ and consider migrating to country y (for concreteness, the United States). The log-income distributions facing these workers in the two countries are given by:

$$
\begin{aligned}
& \log w_{x 1}-\mu_{x 1}+\eta v_{1} \\
& \log w_{y 1}=\mu_{y 1}+v_{1}
\end{aligned}
$$

where $w_{x l}$ and $w_{y l}$ are the Incomes in the source country and in the United States, respectively. The parameter $\mu_{x 1}$ is the population mean of the income distribution in the source country for the first generation, while the parameter $\mu_{y l}$ is the mean income faced by this generation in the United States if all persons in the source country choose to migrate. Note that, In general, the parameter $\mu_{y l}$ will differ from the mean income of U.S. natives. Moreover, because of the dispersion in skills among national origin groups, the parameter $\mu_{y 1}$ will also differ among these groups. The continuous random variable $v_{1}$ measures individual-specific deviations from mean Incomes in the first generation and has a finite varlance.

The functional form in (1) and (2) assumes that $v_{1}$ determines individual earnings in each of the two countries, up to a factor of proportionality. This is equivalent to assuming that earnings are perfectly correlated across the two countries. The factor-loading parameter $\eta$ can be interpreted as the rate of return to skills in the source country (relative to that in the United states), or alternatively as the ratio of the standard deviation in 
earnings between the source country and the United States.

Assume wigration costs (C) are a constant fraction of the individual's earnings in the source country (i.e., $\left.\pi-c / w_{x l}\right)$. If the first generation's objective is to maximlze their own income, the index function guiding the immigration decision is given by:

$$
I-\log \left[w_{y l} /\left(w_{x 1}+C\right)\right]=\left(\mu_{y l}-\mu_{x l}-\pi\right)+(1-\eta) v_{1}
$$

Immigration occurs if $I>0$. Define the Immigrant flow to be positively selected when it has above-average skills $\left[E\left(v_{1} \mid I>0\right)>0\right]$, and negatively selected when it has below-average skills $\left[E\left(v_{1} \mid I>0\right)<0\right]$. Equation (3) Implies that the immigrant flow is positively selected when $\eta<$ 1 , and negatively selected when $\eta>1$. Sk1lled workers choose to reside in countrles that offer relatively higher payoffs for their skills.

Skills are transmitted from generation $t-1$ to generation $t(t>1)$ according to the Markov equations:

$$
\begin{aligned}
& v_{x t}-a_{x t}+\delta_{x} v_{x, t-1}+\epsilon_{x t} \\
& v_{y t}=\alpha_{y t}+\delta_{y} v_{y, t-1}+\epsilon_{y t}
\end{aligned}
$$

where $v_{j t}$ gives the skill variable for persons in the $t^{\text {th }}$ generation in country $j$, and the parameters $\delta_{x}$ and $\delta_{y} 11$ e between zero and one. The random variables $\epsilon_{x t}$ and $\epsilon_{y t}$ have zero means and findte variances, are distributed Independently of skills, and are uncorrelated over time.

The parameters describing the extent to which skills are transuitted 
across generations $\left(\delta_{x}\right.$ and $\left.\delta_{y}\right)$ may differ across countries, and these differences capture the extent to which societies are "open" or "closed." The United States, for instance, is usually considered to be an open society. The parameter $\delta_{y}$ would be expected to be small, and there would be substantial regression towards the mean in earnings across generations.

Equations (4) and (5) imply that a self-selected migration flow in the first generation alters the skill composition of the populations in both the United States and the source country for many subsequent generations. National origin groups that do well in the U.S. labor market in the first generation will tend to do well in subsequent generations. Similarly, the offspring of national origin groups that do poorly will tend to do poorly.

This result is derived from a simple model where the first-generation is selfish in the sense that it does not consider the economic impact of its migration decision on future generations. Suppose instead that parents care about the utility of their children. ${ }^{6}$ In the presence of perfect capital markets, the separation theorem implies that a necessary condition for maximizing dynastic utility is that the first generation's migration decision also maximizes "dynastic income," the present value of the income stream accumulated by the dynasty.

First-generation workers know that the earnings generation process for the $t^{\text {th }}$ generation is described by the earnings distributions:

$$
\begin{aligned}
& \log w_{x t}=\mu_{x t}+\eta v_{x t} \\
& \log w_{y t}=\mu_{y t}+v_{y t}
\end{aligned}
$$


where $\mu_{x t}$ and $\mu_{y t}$ measure the mean Incomes that w11l be observed in the $t^{\text {th }}$ generation; and $\eta$ is the relative price of skills in the source country, assumed constant across generations. Mean incomes ( $\mu_{x t}$ and $\mu_{y t}$ ) vary across generations because the assimilation process could affect future earnings opportunities in the United States for subsequent generations, or because of international differences in rates of economic growth.

Maximization of dynastic utility requires that individuals in the first generation compare dynastic incomes across the two countries. Because the Incomes of future generations depend on the stochastic shocks in the skill transmission process ( $\epsilon_{x}$ and $\epsilon_{y}$ ), which are not observed by the economic agents in the first generation, the immigration decision for risk-neutral workers is guided by the comparison of expected incomes. Workers in the first generation choose whichever income stream has the highest expected value, net of migration costs. As a first-order approximation, workers migrate to the United States when:

$$
\left[1-\frac{\eta\left(1+r-\delta_{y}\right)}{\left(1+r-\delta_{x}\right)}\right] v_{1}>\Delta
$$

where $r$ is the (generational) rate of discount, and $\Delta$ is a constant.

Consider Initially the case where $\delta_{x}-\delta_{y}$, so that the two countries exhibit the same extent of regression towards the mean in earnings.

Equation ( 8 ) Indicates that positive selection will be observed when $\eta<1$, and that negative selection will be observed otherwise. These are precisely the implications of the simpler one-generation model.

Suppose now that $\delta_{x} \neq \delta_{y}$. To understand the role played by differences 
In the skills transmission parameter, consider the case where skills are equally rewarded in the two countries (1,e., $\eta=1$ ). Equation (B) Indicates that highly skilled workers will choose to reside in the country with the highest $\delta$, where their skills are easily transferable to their children. In contrast, unskilled workers have little to lose by woving to a country where skills are not easily transferable to their children, and where the earnings opportunities of future generations are basically determined by random shocks from the $\varepsilon$ distribution. Thus the United States is likely to attract highly-skilled workers from countries that have relatively more open economies and unskilled workers from closed economies.

There is a widespread perception that there is more intergenerational mobility in the United states than in most other countries. This suggests that economic conditions in the United States are particularly appealing for unskilled workers in the source countries, even in the absence of any International differences in the rate of return to skills. Because of the scarcity of data, however, this interesting proposition cannot be systematically tested. Moreover, the avallable (though limited) evidence suggests that "the overall pattern of social mobllity appears to be much the same in the Industrial societies of various Western countries," including the United States (Lipset and Bendix, 1959, p.13).

In view of this finding, accounting for the altrulstic behavior of parents does not alter the key insight provided by the simpler one* generation model. The relative rate of return to skills in the source country determines the type of selection that characterizes both the immigrant population and their ethric offspring. Of course, the practical Importance of this insight depends on the value of the parameter $\delta_{y}$. As 
will be seen in the empirical work below, however, the degree of transmission in the United States is suffictently strong so that the earnings determination process for second-generation Americans greatly resembles that experienced by the first.

\section{Data and Descriptive Analysis}

The empirical analysis uses the Public Use Samples of the four decennial censuses avallable between 1940 and 1970. Each of these censuses (unlike post-1970 censuses) has the important feature that they report the birthplace of the respondent, as well as the birthplace of the respondent's parents. The decennial Censuses for 1940, 1950, and 1960 are a $1 / 100$ sample of the population, while the 1970 Census is a $2 / 100$ sample.

The study is restricted to men aged 25-64 in each of the Censuses, who worked in the civilian sector in the year prior to the Census, were not enrolled in school, and were not self-employed. ${ }^{8}$ These data allow the precise Identification of two generations of Americans: the first generation, composed of the sample of individuals born in a forelgn-country; and the second generation, glven by the sample of persons who were born in the United States, but had at least one parent born in a forelgn country. The generation of the remaining individuals, who had both parents born in the United States, cannot be determined exactly, but for simplicity they will be denoted as "third-generation" Amerlcans. Throughout the analysis, the population of third-generation Amerlcans includes all natives with American-born parents, regardless of racial or ethnic origin.

The top panel of Table 1 reports the average (log) wage rates for firstand second-generation Americans in each of the Censuses. These data are 
TABLE i"

Lod Wages of firut. and Second-Generation dmericans

(Relative to Third Generation)

1. Unadiusted Uages

\begin{tabular}{|c|c|c|c|c|}
\hline Grap & 1940 & 1950 & 1960 & $\underline{1970}$ \\
\hline First Generution: & $\begin{array}{c}1848 \\
(29.60)\end{array}$ & $\begin{array}{c}1082 \\
(13.06)\end{array}$ & $\begin{array}{c}.0818 \\
(17.04)\end{array}$ & $\begin{array}{l}.0383 \\
(11.45)\end{array}$ \\
\hline < 5 Years in U.S. & $\begin{array}{l}.0159 \\
(.48)\end{array}$ & $\cdots$ & $\begin{array}{l}.0910 \\
(-6.45)\end{array}$ & $\begin{array}{r}-1315 \\
(-18.07)\end{array}$ \\
\hline $5+$ Years & $\left(\begin{array}{c}-1883 \\
(30.00)\end{array}\right.$ & $\cdots$ & $\begin{array}{l}-1025 \\
(20.29)\end{array}$ & $\begin{array}{r}.0784 \\
(21.33)\end{array}$ \\
\hline $5-10$ Years & $\cdots$ & $\cdots$ & $\cdots$ & $\begin{array}{l}-0220 \\
(-2.72)\end{array}$ \\
\hline 10-20 Yoarz & $\cdots$ & $\cdots$ & $\cdots$ & (12.32) \\
\hline $20+$ Years & $\cdots$ & $\cdots$ & $\cdots$ & $\begin{array}{l}-1230 \\
(22.98)\end{array}$ \\
\hline Second Generation: & $(2344)$ & $(26.96)$ & $\begin{array}{c}1657 \\
(57.56)\end{array}$ & $\begin{array}{c}.1507 \\
(70.85)\end{array}$ \\
\hline
\end{tabular}

II. Adjusted Yages

\begin{tabular}{|c|c|c|c|c|}
\hline Groves & 1940 & 1950 & 1980 & $\underline{1970}$ \\
\hline Firet Generation: & $\begin{array}{c}.1873 \\
(27.68)\end{array}$ & (12.12) & $\begin{array}{l}.0761 \\
(16.73)\end{array}$ & $\begin{array}{c}-0746 \\
(23.93)\end{array}$ \\
\hline$<5$ Years in U.S. & $\begin{array}{l}.0375 \\
(1.26)\end{array}$ & $\cdots$ & $\begin{array}{l}-.0865 \\
(-6.26)\end{array}$ & $\begin{array}{c}-.0709 \\
(-10.07)\end{array}$ \\
\hline $5+$ Years & $\begin{array}{c}.1904 \\
(28.03)\end{array}$ & $\cdots$ & $\begin{array}{l}.0959 \\
(19.91)\end{array}$ & $(31.56)$ \\
\hline 5-10 Years & $\cdots$ & $\cdots$ & -- & $\begin{array}{l}.0151 \\
(1.99)\end{array}$ \\
\hline $10-20$ Years & -.. & $\cdots$ & $\cdots$ & $\frac{-1067}{(18.64)}$ \\
\hline $20+$ Years & $\ldots$ & $\cdots$ & $\cdots$ & $\frac{-1577}{(28.99)}$ \\
\hline Second Generotion: & $(2316)$ & (i6.67) & $\frac{11097}{(32.54)}$ & $\begin{array}{c}1101 \\
(51.18)\end{array}$ \\
\hline $\begin{array}{l}\text { Sample Sizes: } \\
\text { Ist Generation } \\
\text { 2nd Generation } \\
\text { 3rd Generation }\end{array}$ & $\begin{array}{r}26989 \\
9926 \\
32913\end{array}$ & $\begin{array}{r}6316 \\
13354 \\
63037\end{array}$ & $\begin{array}{r}17566 \\
57629 \\
202907\end{array}$ & $\begin{array}{r}32491 \\
100708 \\
239184\end{array}$ \\
\hline
\end{tabular}

The t-ratios are reported in parentheses. The adjusted wage differentials control for differences in educstion, age (and age squared), marital status, and metropolitan residence. 
differenced from the average values observed in the sample of thirdgeneration workers. The table also reports the summary statistics for a number of 1mmigrant cohorts. The 1940 and 1960 Censuses permit the Identiflcation of two waves: those who arrived in the flve-year perlod prior to the survey, and those who have been in the U.S. longer than flve years. 9 The 1970 Census permits the Identification of additional waves.

The data reveal the well-known decline in earnings (relative to thirdgeneration Amerlcans) among successive lmmigrant cohorts (Borjas, 1985). In 1940, the typlcal Immlgrant who has been in the U.S. fewer than five years earned 1.6 percent more than a third-generation American. This slight wage advantage declines to -9.1 percent in 1960 and to -13.2 percent in 1970 .

Each of the Census cross-sections Indicates that the second generation has higher earnings than the first and than the third. In 1970, secondgeneration workers earned 11 percent more than the flrst, and 3 percent more than the third. As Carliner (1980) and Chlswlck (1977) note, it seems that second-generation Americans earn more than both their parents and their children. This concluston, however, is premature. In any Census crosssection, the family tles among the three generations Identiflable in the data are tenuous. At the time of the survey, many members of the firstgeneration have just arrived in the United States and have no native descendants yet employed in the U.S. labor market. Second-generation Americans of working age can only be descendants of Immigrants who have been In the country for at least two or three decades. Therefore, as long as cohort differences among first-generation workers are Important, and as long as these differences are partlally transmitted to their children, the comparison of first- and second-generation earnings in a cross-section 
provides a misleading portrait of intergenerational mobility.

Similarly, the persons who can be Identified as members of the "thirdgeneration" are a motley collection of varlous ethnic groups whose presence In the United States may date 30 or 40 years, or more than 100 or 200 years. It is also unlikely that these so-called third-generation workers are direct descendants of the Imolgrants enumerated in the Census cross-section. After all. this would require that working-age Immigrants have American-born grandchildren who are also of working age. Obviously, because of these data problems, It is difficult to Infer anything about the Intergenerational mobility experienced by the third-generation in the United States.

The Census data, however, do allow the study of economic mobility between the first and second generations. These comparisons, however, must be designed so as to ensure that the Imolgrants are the parents of the second-generation Americans Identifled in the Census. A number of alternative methodologies are avallable. For example, In any single Census cross-section, Immigrants who have been in the United States for a sufficiently long period of time (and hence can have American-born children of working age) can be compared to second-generation workers.

The 1940, 1960, and 1970 Censuses permit the contrast of the earnings of second-generation workers with those of Immigrants who have been in the U.S. longer than five years. Although this is a crude method of ensuring familial links across generations, the eamings advantage of secondgeneration workers over their "parents" declines substantially (to about 3-6 percent) In the 1960 and 1970 Censuses after this correction is made.

A similar result can be drawn from Intercensal comparisons of first- and second-generation workers. These comparisons Increase the likelihood that 
the two generations are linked through family ties. The data in Table 1 indicate that first-generation workers present in the 1940 Census earn about 18 percent more than third-generation workers, while first-generation workers in the 1950 Census earn about 11 percent more than third-generation workers. The data also show that the children of these immigrants, namely the second-generation workers in the 1960 or 1970 Census, earn only about 15 to 17 percent more than the third generation. There is only a slight improvement, and perhaps even a decline, in the relative earnings of the second-generation as compared to the first. 10

The bottom panel of Table 1 continues the descriptive analysis by presenting the relative wage differentials after controlling for differences in observable demographic characteristics, including education, age, marital status, and metropolitan residence. 11 The (log) wage regressions are estimated separately for each generation in each Census. The predicted wage of the various generations is calculated using the means of the demographic variables observed in the sample of immigrants. The adjusted differentials indicate that there is little improvement in relative earnings between the first and second generations. In fact, the immigrant population in 1940 has higher adjusted earnings than comparable second-generation workers in 1960 or 1970. The data thus hint at the possibility of some regression towards the mean between the first and second generations.

The intercensal linkage between parents and children can be further improved by focusing on workers in specific age groups. For example, the children of tmigrants aged $25-44$ in 1940 are likely to be relatively young in 1970, while the children of immigrants aged 45-64 in 1940 are likely to be relatively older in 1970.12 Table 2 presents both unadjusted and 


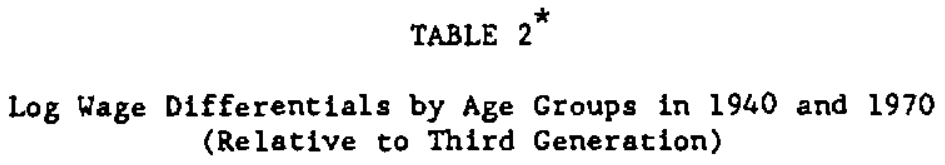

I. Unadjusted Wages

Group

Men Aged 25-44

Men Aged 45-64

Men Aged 25-64

II. Adjusted Wages

Group

Men Aged 25.44

Men Aged 45-64

Men Aged 25-64

\section{First Generation in 1940}

$$
\begin{gathered}
.1975 \\
(23.61)
\end{gathered}
$$

.1281

$(12.77)$

$$
.1848
$$

$(29.60)$
Second Generation in 1980

$$
\begin{array}{r}
.1624 \\
(52.73)
\end{array}
$$

.1400

(45.62)

.1507

$(70.85)$

Second Generation in 1980

.0953

$(28.46)$

(23.11)

.1209

$(38.92)$
.1101

(51.18)

* The t-ratios are reported in parentheses. The adjusted wage differentials control for differences in education, age (and age squared), marital status. and metropolitan residence. 
adjusted wage differentials among the varlous generations for groups aged 25-44 and 45-64 in 1940 and 1970. The ( $\log$ ) wage of young immigrants in 1940 (relative to young third-generation workers) is .20, while the relative wage of their children in 1970 (many of whom would be aged $25-44$ in 1970) is 16. Similarly, older immigrants in 1940 earned about 12.8 percent more than older third-generation workers, while their children earned about 14 percent more than older-third generation workers in 1970 . Therefore, refining the data so as to provide a better linkage between parents and children across Censuses does not alter the Implication of the descriptive analysis. There is little increase (and there may well be a slight decline) in relative wages between the first and second generations.

\section{National Origin and Intergenerational Mobility}

Studies of immigrant labor market performance have found substantial dispersion in relative earnings among national origin groups (Borjas, 1987). These skill differentials among national origin groups are likely to be partially transmitted to their ethnic offspring. Table 3 begins the analysis by reporting the earnings of first-and second-generation workers (relative to the earnings of third-generation Americans) for a large number of national origin groups in the 1940-1970 period. The ethnicity of second. generation Americans is determined from the father's country of birth (unless only the mother is foreign-born, in which case it is determined from the mother's country of birth). 13

The source countries listed in the table are the ones which contain sufflcient observations of both first- and second-generation Americans in the data. In each Census, the analysis is restricted to the national origin 
TABLE 3

Mational origin and the Log Wages of First. and Second-Generation Americans

1940

1950

1960

1970

16tGen, 2nd Gen, 1st Gen. 2nd Gen. 15t Gen, 2nd Gen. 1st Gen. Znd Gen.

\begin{tabular}{|c|c|c|c|c|c|c|c|c|}
\hline \multicolumn{9}{|l|}{ Europe: } \\
\hline Austria & .279 & .296 & .168 & .241 & .182 & .238 & .266 & .211 \\
\hline Czechos lovak is & .277 & .258 & .109 & .167 & .190 & .192 & .192 & .137 \\
\hline Dermerk & .291 & .126 & .039 & .208 & .243 & .195 & .190 & .119 \\
\hline France & .229 & .278 & .053 & .236 & .144 & .188 & .180 & .220 \\
\hline Germeny & .198 & .245 & .190 & .171 & .199 & .159 & .229 & .128 \\
\hline Greace &. .103 & $=.010$ & $\cdot .003$ & .051 &. .177 & .145 & $\cdot .103$ & .189 \\
\hline Hungary & .267 & .315 & .302 & .240 & .130 & .242 & 190 & .204 \\
\hline Ireland & .209 & .343 & .023 & .181 & .050 & .184 & .032 & .186 \\
\hline Itely & .159 & .124 & .111 & .104 & .090 & .151 & .054 & .137 \\
\hline Nether lands & .105 & .077 & .114 & .227 & .123 & .179 & .133 & .161 \\
\hline Norway & .270 & .140 & .317 & .108 & .326 & .107 & .234 & .144 \\
\hline Poland & .222 & .165 & .154 & .168 & .119 & .188 & .108 & .154 \\
\hline Portugal & .051 & .021 & $\cdot .062$ & .102 & .040 &. .025 &. .122 &. .003 \\
\hline Romanis & .295 & .216 & .282 & .313 & .223 & .344 & .184 & .330 \\
\hline Spoin & .065 & .215 & -.054 & .180 & .064 & .129 & -.088 & .106 \\
\hline Sweden & .262 & .267 & .199 & .214 & .209 & .201 & .218 & .178 \\
\hline Suitzerland & .198 & .352 & .090 & .099 & .155 & .131 & .311 & .117 \\
\hline United Kinodorn & .317 & .363 & .229 & .267 & .240 & .222 & .236 & .208 \\
\hline USSR & .276 & .280 & .200 & .204 & .120 & .280 & .150 & .320 \\
\hline rugoslavia & .299 & .337 & .186 & .122 & .175 & .210 & .104 & .173 \\
\hline \multicolumn{9}{|c|}{ Asila and Africa: } \\
\hline Chine & - - & $\cdots$ & $\cdots$ & $\cdots$ & $\because .177$ & .109 & -.085 & .149 \\
\hline Indis & $\cdots$ & $\cdots$ & $\cdots$ & $\cdots$ & .119 & .318 & .236 & .131 \\
\hline Isroel & $\cdots$ & $\ldots$ & $\cdots$ & $\cdots$ & -.011 & .432 & .140 & .490 \\
\hline Japan & $\cdots$ & $\cdots$ & -.212 & -.092 &. .172 & .072 & .123 & .137 \\
\hline Kored & $\cdots$ & $\cdots$ & -- & - - & -.303 & .142 & -.009 & .183 \\
\hline Phillipines & $\cdots$ & $\cdots$ & $\cdots$ & $\cdots$ & $\cdot .249$ & -.065 & -.123 & -.058 \\
\hline \multicolumn{9}{|l|}{ Amer fcas: } \\
\hline Argent ins & $\cdots$ & $\cdots$ & $\cdots$ & $\cdots$ & .185 & .324 & .101 & .174 \\
\hline Brazil & $\cdots$ & $\cdots$ & $\cdots$ & $\cdots$ & .111 & .004 & .090 & -.004 \\
\hline Canada & .252 & .159 & .207 & .121 & .192 & .130 & .176 & .114 \\
\hline Cubs & -.004 &. .126 & -.296 & -.145 & $\cdot .232$ & .077 & -.213 & -.025 \\
\hline Jama ice & $\cdots$ & $\cdots$ & $\cdots$ & $\cdots$ &. .416 & .043 & -.085 & .094 \\
\hline Mexico & $\cdot .496$ & $\cdot .663$ & -.392 & -.236 & -.327 & -.227 & -.340 & -.161 \\
\hline
\end{tabular}


groups which contain at least 25 observations in both the first- and secondgeneration samples. In the 1940 Census, this sample restriction leads to 23 source countries (located mostly in Europe) which account for 97 percent of the immigrant population. The selected countries listed in the table, therefore, almost exhaust the national origin groups that could be used to analyze the intergenerational mobility of immigrants.

Table 3 reveals substantial dispersion among ethnic groups in the earnings of second-generation Americans. In 1970, for 1nstance, secondgeneration Americans of British ancestry earned about 20.8 percent more than third-generation Americans, while second-generation Canadians earned 11.4 percent more, and second-generation Mexicans earned 16.1 percent less.

To assess the extent of intergenerational mobility, it is useful to contrast the (relative) earnings of immigrants in 1940 with the (relative) earnings of second-generation Americans in 1970. The strong relationship between the relative earnings of the two generations is documented in Table 4. which reports GLS estimates of regressions of the form: ${ }^{14}$

$$
z_{2 j}(1970)-a+\delta z_{1 j}(1940)+c_{j}
$$

where $z_{1 j}(t)$ gives the earnings (relative to those of the third generation) of the $i^{\text {th }}$ generation from source country $j$ in Census year $t$. The regressions were also estimated using other combinations of Census years (such as 1940 for the first generation and 1960 for the second) without altering the main results of the study.

The first row of Table 4 reports estimates of (9) using the unadjusted earnings differentials presented in Table 3 . The constant term indicates a 
TABLE 4

Relationship Between the Earnings of the First-and Second-Generations*

\begin{tabular}{|c|c|c|c|c|c|c|}
\hline Bow & Incercept & $z_{1}(1940)$ & $z_{1} \frac{(1970)}{2}$ & $\mathrm{~B}^{2}$ & $\begin{array}{l}\text { Sample } \\
\text { Stze }\end{array}$ & Remarks \\
\hline 1. & $\begin{array}{l}.0695 \\
(4.19)\end{array}$ & $\begin{array}{l}.4465 \\
(6.85)\end{array}$ & - & .691 & 23 & $\ldots$ \\
\hline 2. & $\begin{array}{l}.0887 \\
(2.17)\end{array}$ & $\begin{array}{l}.3627 \\
(2.06)\end{array}$ & - & .176 & 22 & Omits Mexico \\
\hline 3. & $\begin{array}{l}.0658 \\
(5.67)\end{array}$ & $\begin{array}{l}.2696 \\
(5.10)\end{array}$ & - & .553 & 23 & $\begin{array}{l}\text { Uses Adjusted } \\
\text { Wage }\end{array}$ \\
\hline 4. & $\begin{array}{l}.0692 \\
(4.40)\end{array}$ & $\begin{array}{l}.4967 \\
(8.91)\end{array}$ & - & .791 & 23 & $\begin{array}{l}\text { Young Sample: } \\
\text { Men Aged 25-44 }\end{array}$ \\
\hline s. & $\begin{array}{l}.0923 \\
(5.28)\end{array}$ & $\begin{array}{l}.3785 \\
(4.34)\end{array}$ & . - & .498 & 21 & $\begin{array}{l}\text { O1der Sample: } \\
\text { Men Aged 45-64 }\end{array}$ \\
\hline 6. & $\begin{array}{l}.0572 \\
(4.74)\end{array}$ & $\begin{array}{l}.2334 \\
(4.90)\end{array}$ & - & .534 & 23 & $\begin{array}{l}\text { Young Sample } \& \\
\text { Adjusted Wage }\end{array}$ \\
\hline 7. & $\begin{array}{l}.0876 \\
(6.03)\end{array}$ & $\begin{array}{l}.2433 \\
(2.94)\end{array}$ & - & .313 & 21 & $\begin{array}{l}\text { Older Sample } 8 \\
\text { Adjusted Wage }\end{array}$ \\
\hline 8. & $\begin{array}{l}.0666 \\
(3.94)\end{array}$ & $\begin{array}{l}.5767 \\
(3.76)\end{array}$ & $\begin{array}{l}-.1840 \\
(-.94)\end{array}$ & .704 & 23 & - \\
\hline 9. & $\begin{array}{l}.0617 \\
(3.72)\end{array}$ & $\begin{array}{l}.2548 \\
(3.72)\end{array}$ & $\begin{array}{l}.0442 \\
(.35)\end{array}$ & .556 & 23 & $\begin{array}{l}\text { Uses Adjusted } \\
\text { Wage }\end{array}$ \\
\hline 10. & $\begin{array}{l}.0687 \\
(4.04)\end{array}$ & $\begin{array}{l}.5083 \\
(3.57)\end{array}$ & $\begin{array}{c}-.0157 \\
(-.09)\end{array}$ & .791 & 23 & Young Sample \\
\hline 11. & $\begin{array}{l}.0952 \\
(4.91)\end{array}$ & $\begin{array}{l}.4305 \\
(2.67)\end{array}$ & $\begin{array}{c}-.0818 \\
(-.39)\end{array}$ & .502 & 21 & Older Sample \\
\hline 12. & $\begin{array}{l}.0445 \\
(2.47)\end{array}$ & $\begin{array}{l}.2760 \\
(2.23)\end{array}$ & $\begin{array}{l}.1345 \\
(.22)\end{array}$ & .698 & 23 & $\begin{array}{l}\text { Young Sample \& } \\
\text { Adjus ted Wage }\end{array}$ \\
\hline 13. & $\begin{array}{l}.0800 \\
(3.62)\end{array}$ & $\begin{array}{l}.2016 \\
(2.25)\end{array}$ & $\begin{array}{l}.1134 \\
(.74)\end{array}$ & .350 & 21 & $\begin{array}{l}\text { Older Sample \& } \\
\text { Adjusted Wage }\end{array}$ \\
\hline
\end{tabular}

*The t-ratios are reported in parentheses. 
7.0 percent increase in earnings potential across generations that is common to all national origin groups. One plausible reason for this upward "shift" in the earnings profile is that second-generation Americans are not only better educated, but also go through the American educational system, which employers presumably value more than the schooling system of other countries. In addition, second-generation Americans are more likely to be proficient in English, better inforwed about opportunities in the U.S. labor market, and less tied to old neighborhoods and ethnic enclaves. It is not surprising, therefore, to find that second-generation Americans experience a common improvement in their earnings opportunities.

Second, there is some regression towards the mean across generations. This regression towards the mean, however, is not sufficient for national origin to become a trivial determinant of the earnings of second-generation Americans. In particular. the estimate of the coefficient $\delta$ in equation (9) is . 45. This magnitude implies that even after three generations, the earnings of third-generation ethnic groups depend on the earnings of their immigrant grandparents. Finally, the earnings of first-generation national origin groups explain a large fraction of the variance in the earnings of second-generation ethnic groups (the $R^{2}$ is .69). 15

A potential problem with the analysis is that the data contain an important outlier, Mexico. Both Mexican Immigrants and their children perform very poorly in the United states. This single observation could, in principle, be driving many of the results. Row 2 of Table 4 reestimates the regression after omitting the Mexican national origin group. Although the estimated transmission coefficient declines somewhat (to .36), it is apparent that this single observation is not responsible for the link 
between the earnings of first- and second-generation Americans.

Additional problems arise because the independent variable, the relative wage of Immigrants, may be improperly defined. In particular, the result that all national origin groups experience a common increase in earnings across generations is obtained from regressions which do not account for the assimilation process experienced by the first generation. It is possible that if the second-generation wage were related to the wage of fully assimilated Immigrants, the improvement across generations would disappear.

This measurement problem, however, is unlikely to be the source of the positive intercept in the regressions. After all, the regressions in Table 4 use the 1940 earnings of immigrants as the Independent variable. Over 9.8 million Immigrants entered the United States between 1911 and 1930 , but only half a million entered during the 1930 s (U.S. Immigration and Naturalization Service, 1989, p, 1). Therefore, almost all immigrants enumerated in the 1940 Census have been in the United States for more than 10 years, and are likely to have experienced substantial assimilation.

Moreover, using the 1970 Census, it is possible to estimate the relative wage of Immigrants who arrived In the United States prior to 1950, and who have been in the country more than 20 years. I calculated this statistic for each of the 32 national origin groups listed in Table 3 . The relationship between the 1970 wage of second-generation workers and the 1970 wage of this early lmigrant wave is given by:

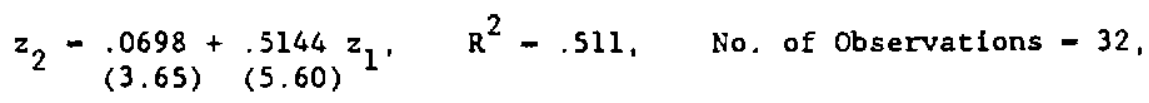


where $z_{1}$ is the wage of the $1^{\text {th }}$ generation (relative to that of the third). and the $t$-ratios are reported in parentheses. The regression coefficlents in (10) are remarkably similar to those presented in the first row of Table 4. It seems unlikely, therefore, that problems in defining the immigrant wage are responsible for the common improvement across generations.

It is also of interest to determine if the same degree of intergenerational mobility is observed between the earnings of demographically comparable first- and second-generation Americans. The adjusted earnings (relative to the earnings of third-generation workers) are predicted from regressions estimated for each generation by Census and national origin group (and are evaluated at the means of the varlables observed in the sample of immigrants). The regressors included education, age (and age squared), marital status, and metropolitan residence.

Row 3 of Table 4 reports the estimate of equation (9) using these adjusted differentials. The earnings of Immigrants are an important determinant of the earnings of their children, even after controlling for differences in demographic characteristics between the groups. The estimated $\delta$ declines to .27 , and the constant term declines to 6.6 percent. The variation in the adjusted earnings of first-generation national origin groups explains over half of the varlation in the adjusted earnings of second-generation ethnic groups.

Rows 4-7 of Table 4 report regression estimates where the (relative) earnings of second-generation workers aged 25.44 (or 45-64) in 1970 are related to the earnings of similarly-aged immigrants in 1940. As noted earlier, this comparison provides a better link between parents and children in intercensal comparisons. The regression estimates are quite similar to 
those reported above. For Instance, In the wage regression for younger workers (row 4) the intercept is 6.9 percent and the slope is .5, while in the wage regression for older workers (row 5) the intercept is 9.2 percent and the slope is .4 .

Finally, the remalning rows of Table 4 investigate if the earnings of second-generation workers in 1970 are related to the earnings of any other Imigrant group, not just the group observed in 1940 which is presumably composed of their parents. Consider the regression model:

$$
z_{2 j}(1970)-\alpha+\delta z_{1 j}(1940)+\beta z_{1 j}(1970)+\epsilon_{j}
$$

Equation (11) generalizes (8) by relating the 1970 earnings of secondgeneration workers to the earnings of their Immigrant fathers, as well as to the earnings of Immigrants present in the United States in 1970.

Rows 8-13 of Table 4 report the estimated parameters. The varlable measuring the 1970 earnings of Immigrants is never significantly different from zero, and has little effect on the remalning coefficients. Therefore, the avallable data Indicate that the earnings of second-generation workers are much more heavily influenced by the earnings of their parents than by the earnings of current Immigrants from the same source country. This finding suggests that the Intercensal comparisons used in this paper provide a useful methodology for analyzing economic mobllity between first- and second-generation Americans.

In sum, the regressions reported in Table 4 suggest two substantive conclusions. On average, second-generation Americans experience an increase in economic well-being relative to their parents that is not experienced by 
the third generation. This intergenerational shift increases earnings by about 7 percent between the first and second generations. In addition, there is a strong link between the earnings of first and second generation workers. The intergenerational transmission parameter is sufficiently high so that the labor market performance of Immigrants will have long-term effects on the U.S. economy. In effect, Immigration policies that alter the skill level of the 1 molgrant flow will also partly determine the skill level of their children and grandchildren.

\section{Source Country Characteristics and Earnings}

The regressions reported in Table 4 do not directly test the Implications of the theoretical framework presented in Section II. A more direct test pursues the insight that the same source country characteristics determine the earnings of both 1mmigrants and second-generation workers.

To assess the Importance of source country characteristics, the wages of first- and of second-generation Americans (relative to the wage of thirdgeneration workers) are related to a number of country-speciflc variables, Including the country's (log) per capita GNP, the extent of income Inequality in the country's income distribution, a dimmy variable indicating If the country lists English as an official language, and the distance of the source country from the United States. 16 My measure of Income Inequality in the source country is given by the ratio of income accruing to the top 10 percent of the households to the Income accruing to the bottom 20 percent of the households. A key prediction of the model is that Immigrant earnings are lower if the source country has relatively high payoffs to skills. As long as skills are partially transmitted across generations, the 
income inequality variable should have a negative impact on the earnings of both first- and second-generation workers.

Regressions (1) and (2) of Table 5 show the 1mpact of source country characteristics on the wages of immigrants and their children. The adjusted and unadjusted (relative) wages used in the regression are obtained from the 1970 Census. 17 The "second-stage" regressions are then estimated using generalized least squares. The data Indicate that immigrant earnings are higher if the group originates in a high-income country or in a country that has English as an official language, and are lower if the group originates in a country with substantial inequality in the income distribution (though this effect is significant only in the regression that uses unadjusted earnings). 18

Table 5 also documents that these source country characteristics determine the earnings of second-generation ethnic groups in roughly the same way. The children of 1mmigrants earn more $1 f$ their parents originated In high-GNP countries or In countries where English is an offlcial language. These effects, however, disappear once differences in demographic characteristics are controlled for. More important, the Income inequality variable has the same qualitative impact on the earnings of first-and second-generation Americans. In particular, second-generation workers whose parents originated in countries with substantial income inequality, and were therefore more likely to be negatively selected, have lower earnings than other ethnic groups.

The variables used as regressors in Table 5 measure relevant sourcecountry characteristics circa 1970. In principle, the per-capita income and Income Inequality variables that determine the 1970 earnings of second- 


\begin{abstract}
tagle 5
Source-Country characteristics and the 1970 Earnings of first- and Second-Generation Americans
\end{abstract}

\begin{tabular}{|c|c|c|c|c|c|c|}
\hline \multirow[b]{2}{*}{ Variable } & \multicolumn{2}{|c|}{ first Generation } & \multicolumn{4}{|c|}{ Second Generation } \\
\hline & (1) & (2) & (1) & (2) & (3) & (4) \\
\hline \multirow[t]{2}{*}{ Intercept } & -1.2923 & -1.0585 & -.3551 & .2808 & $\cdot .4578$ & $\cdot .0393$ \\
\hline & $(-6.26)$ & $(.5 .13)$ & $(-1.61)$ & $(2.17)$ & $(-2.46)$ & $(\cdot .12)$ \\
\hline \multirow[t]{2}{*}{ Lop(Per Caplta GNP) } & .1454 & .1268 & .0460 & -.0184 & .0598 & .0008 \\
\hline & (6.72) & $(5.86)$ & $(2.09)$ & $(-1.39)$ & $(3.34)$ & $(.02)$ \\
\hline \multirow[t]{2}{*}{ Incone Inequality } & -.0195 & $\cdot .0068$ & $\cdot .0190$ & $\cdot .0110$ & $\cdot .0185$ & -.0064 \\
\hline & $(-2.41)$ & $(-.82)$ & $(-4.21)$ & $(-4.06)$ & $(-4.30)$ & $(-.71)$ \\
\hline \multirow{2}{*}{$\begin{array}{l}\text { English is official } \\
\text { Language }\end{array}$} & .1047 & .0361 & .0826 & .0049 & .0736 & .0722 \\
\hline & $(2.80)$ & $(.97)$ & $(3.00)$ & $(.31)$ & $(3.49)$ & $(1.87)$ \\
\hline \multirow[t]{2}{*}{ Oistance from U.S. } & .0326 & .0264 & .0467 & .0126 & .0383 & .0416 \\
\hline & $(3.43)$ & $(2.73)$ & $(4.59)$ & $(2.22)$ & $(5.61)$ & $(2.91)$ \\
\hline $\begin{array}{l}\text { first-Generation Wage } \\
\text { in } 1940\end{array}$ & $\cdots$ & $\cdots$ & $\cdots$ & $\cdots$ & $\cdots$ & $\begin{array}{l}.2392 \\
(1.48)\end{array}$ \\
\hline$R^{2}$ & .683 & .611 & .782 & .606 & .891 & .838 \\
\hline $\begin{array}{l}\text { Controls for 0emographic } \\
\text { Characteristics }\end{array}$ & no & Yes & Ho & Yes & Ho & No \\
\hline $\begin{array}{l}\text { Deletes Comminist } \\
\text { Countries }\end{array}$ & No & No & No & No & res & No \\
\hline \multicolumn{7}{|c|}{ 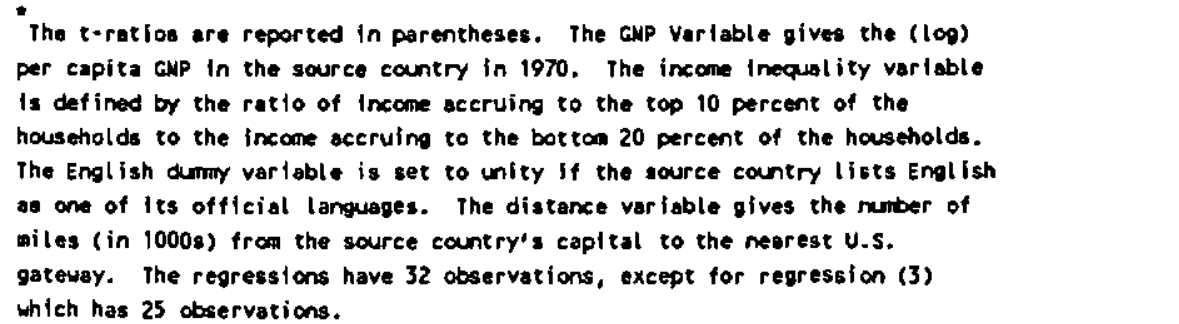 } \\
\hline
\end{tabular}


generation workers are those that guided the migration decision of their parents, and not those observed in the source country in 1970. These data, however, are not available for most source countries prior to World War II. The regressions for second-generation workers, however, were reestimated using alternative measures, such as the 1950 per-capita GNP in the source country, with little change in the results. Moreover, as regression (3) of Table 5 indicates, the results are unaffected when the equation for secondgeneration workers is reestimated in the subsample of countries that did not undergo a Communist revolution. The omission of Communist regimes from the sample deletes the countries where the income distribution is likely to have changed the most over the last few decades, and reduces the measurement error in the income inequality variable.

Finally, regression (4) of Table 5 reestimates the regression for the second generation after including the relative income level of their parents (1n addition to the source country characteristics). The inclusion of parental income significantly reduces the impact of both the GNP and the income inequality variables. Source-country characteristics, therefore, affect second-generation earnings mostly through their impact on the skill level and earnings of immigrants, although this finding must be interpreted with some caution because of the small number of observations and the multicollinearity among the variables. I should also note that this conclusion is unchanged if the regressions (results not shown) are estimated in the samples of first- and second-generation workers aged 25-44 or 45-64.

The avallable data allow one additional test of the theoretical framework. In particular, the theory implies that increases in the size of the immigrant flow (due perhaps to low per-capita incomes or migration 
costs) dilute the Intensity of the selection. In other words, if the Immigrant flow is positively selected, an increase in the size of the immigrant flow should be assoclated with lower average U.S. earnings. Conversely, if the 1mmigrant flow is negatively selected, an increase in the size of the immigrant flow should be associated with higher average U.S. earnings.

Consider the following regression model:

$$
\log w_{1}-\alpha_{0}+\alpha_{1} r_{1} \cdot p_{1}+a_{2}\left(1-r_{1}\right) \cdot p_{1}+a_{3} a_{1}+\epsilon_{1}
$$

where $w_{1}$ are the 1970 earnings of first- or second-generation workers originating in country 1; $P_{1}$ is the fraction of the source country's population that migrated to the United States; $r$ is a dummy variable set to unity if the source country has a more unequal income distribution than the United States and zero otherwise; and $\sigma$ is the income inequality variable used earlier. The theory implies that $a_{1}>0, a_{2}<0$, and $\alpha_{3}<0$.

Table 6 presents the estimated earnings regressions for both first- and second-generation workers. In analyzing the earnings of 1mmigrants in 1970, the variable $p$ is defined as the ratio of the number of 1mmigrants present in the United States in 1970 to the 1970 source country's population. Because the earnings of second-generation workers should mirror the selection that characterized the migration of their parents, the regression on the 1970 earnings of second-generation workers defines $p$ as the ratio of the number of Immigrants present in the United States in 1940 to the 1940 source country's population.

The inequality variable has a negative and signiflcant effect on the 
TABLE 6 "

S1ze of Imraigrant Flow and the 1970 Earnings of Firat* and Second-Generation Amaricans

\begin{tabular}{|c|c|c|c|c|c|c|c|c|}
\hline \multirow[b]{2}{*}{ Variable } & \multicolumn{3}{|c|}{ First Generation } & \multicolumn{5}{|c|}{ Second Generation } \\
\hline & $(1)$ & $12)$ & (3) & (1) & (2) & (3) & (6) & $(5)$ \\
\hline Intercept & $\begin{array}{l}.3862 \\
(5.61)\end{array}$ & $\begin{array}{l}.3055 \\
(5.82)\end{array}$ & $\begin{array}{r}-1.0531 \\
(-2.52)\end{array}$ & $\begin{array}{l}.2894 \\
(8.84)\end{array}$ & $\begin{array}{l}.1817 \\
(9.46)\end{array}$ & $\begin{array}{l}-.3768 \\
(-1.34)\end{array}$ & $\begin{array}{l}.1759 \\
(2.79)\end{array}$ & $\begin{array}{l}\cdot .0218 \\
(\cdot .06)\end{array}$ \\
\hline $\begin{array}{l}\text { size of Immigrant flow } \\
\text { if Country Has Less } \\
\text { Inequality than U.S. }\end{array}$ & $\begin{array}{l}\cdot .0609 \\
(-3.73)\end{array}$ & $\begin{array}{l}-.0538 \\
(-4.61)\end{array}$ & $\begin{array}{l}-.0160 \\
(-.69)\end{array}$ & $\begin{array}{l}-.0163 \\
(-1.39)\end{array}$ & $\begin{array}{l}-.0102 \\
(-1.59)\end{array}$ & $\begin{array}{l}-.0036 \\
(-.22)\end{array}$ & $\begin{array}{l}-.0163 \\
(-1.26)\end{array}$ & $\begin{array}{l}-.0041 \\
(-.16)\end{array}$ \\
\hline $\begin{array}{l}\text { Size of Imotigrant Flow } \\
\text { if Country Mas More } \\
\text { Inequallty than U.S. }\end{array}$ & $\begin{array}{l}-.0115 \\
(-.60)\end{array}$ & $\begin{array}{l}-.0151 \\
(-.77)\end{array}$ & $\begin{array}{l}.0443 \\
(.20)\end{array}$ & $\begin{array}{l}-.0276 \\
(-.86)\end{array}$ & $\begin{array}{l}-.0027 \\
(-.16)\end{array}$ & $\begin{array}{l}.0165 \\
(.46)\end{array}$ & $\begin{array}{l}-.0227 \\
(-.31)\end{array}$ & $\begin{array}{l}.0186 \\
(.21)\end{array}$ \\
\hline Income Inequality & $\begin{array}{l}-.0467 \\
(-4.09)\end{array}$ & $\begin{array}{l}-.0252 \\
(-3.06)\end{array}$ & $\begin{array}{l}-.0255 \\
(-2.46)\end{array}$ & $\begin{array}{l}-.0274 \\
(\cdot 3.72)\end{array}$ & $\begin{array}{l}-.0126 \\
(-3.08)\end{array}$ & $\begin{array}{l}-.0217 \\
(\cdot 3.50)\end{array}$ & $\begin{array}{l}-.0127 \\
(-1.16)\end{array}$ & $\begin{array}{r}-.0085 \\
(-.80)\end{array}$ \\
\hline $\begin{array}{l}\text { First-Generation Wage } \\
\text { in } 1940\end{array}$ & $\cdots$ & $\cdots$ & $\cdots$ & $\cdots$ & $\cdots$ & $\cdots$ & $\begin{array}{l}.2670 \\
(1.63)\end{array}$ & $\begin{array}{l}.2648 \\
(1.26)\end{array}$ \\
\hline Log(Per Capito GMP) & $\cdots$ & $\cdots$ & $\begin{array}{l}.1281 \\
(3.53)\end{array}$ & $\cdots$ & $\cdots$ & $\begin{array}{l}-0497 \\
(1.82)\end{array}$ & -.. & $\begin{array}{r}-.0003 \\
(-.01)\end{array}$ \\
\hline $\begin{array}{l}\text { English is official } \\
\text { Language }\end{array}$ & $\cdots$ & $\cdots$ & $\begin{array}{l}.1507 \\
(3.97)\end{array}$ & $\cdots$ & $\cdots$ & $\begin{array}{l}.0888 \\
(2.70)\end{array}$ & $\cdots$ & $\begin{array}{l}.0771 \\
(1.57)\end{array}$ \\
\hline Distance from U.S. & $\cdots$ & $\cdots$ & $\begin{array}{l}.0372 \\
(2.15)\end{array}$ & $\cdots$ & $\cdots$ & $\begin{array}{l}.0469 \\
(3.63)\end{array}$ & $\cdots$ & $\begin{array}{l}.0607 \\
(2.30)\end{array}$ \\
\hline$R^{2}$ & .570 & .528 & .811 & .639 & .461 & .786 & .745 & .840 \\
\hline $\begin{array}{l}\text { Controls for Demographic } \\
\text { Charocteristics }\end{array}$ & No & res & No & No & Yes & No & No & No \\
\hline
\end{tabular}

The $t$-ratios are reported in parentheses. The size of the imolgrant flow is given by the ratlo of the number of immigrants in 1970 to the population of the source cantry in 1970 in the first-generation regressions, and by the same ratio messured as of 1940 for the second-generation regressions. 
earnings of both first- and second-generation workers in this alternative specification of the model [see regressions (1) and (2)]. The sign pattern of $\alpha_{1}$ and $\alpha_{2}$, however, is only partly consistent with the theory. For instance, the larger the immigrant flow from a country with an egalitarian income distribution, the lower the earnings of both first- and secondgeneration workers. Increasing $p$ in countries with more income inequality than the United States, however, does not have a significantly positive effect on earnings.

The additional columns presented in Table 6 present alternative specifications of equation (12). As before, the results for the second generation are very sensitive to the introduction of parental earnings. The inclusion of the 1940 earnings of immigrants (which itself is only marginally significant) greatly reduces the impact of the other variables in the equation. In addition, expanding (12) to include other source country characteristics (such as per-capita GNP and English language) generally reveals that the source country characteristics are more important than the interaction terms between income inequality and the size of the immigrant flow (see regression (3) in Table 6).

Overall, the results in Tables 5 and 6 suggest that ethnic wage differentials can, to some extent, be understood in terms of the national origin differences documented in immigrant labor market performance. In particular, the same source country characteristics that determine economic success for first-generation Americans are important determinants of the economic success of their children. 
VI. Summary

This paper presented an analysis of the intergenerational mobility of Imolgrants. As long as skills are partly transwitted across generations, the same types of selection that characterize the Imolgrant flow are likely to characterize their offspring. Hence the same source country characteristics that are such cruclal determinants of the labor market experiences of Immigrants will Influence the experiences of their children. In effect, current immigration policy determines tomorrow's differences in the labor market experiences of U.S. -born ethnic groups.

The empirical analysis used the four decennial Censuses available between 1940 and 1970. These data allow the precise Identiflcation of two generations of Americans, and Indicate a signiflcant relationship between the earnings of the flrst and second generations. The data also suggest the existence of regression towards the mean across generations. Nevertheless, the analysis indicates that the wage of second-generation ethnic groups cruclally depends on the wage of the first-generation national origin group. In addition, the evidence reveals that the earnings of second-generation Americans are strongly affected by varlables describing the economic opportunities avallable in the home of their ancestors. 
FOOTNOTES

*Professor of Economics, University of California, San Diego, and Research Associate, National Bureau of Economic Research. I am grateful to Gary Becker, James Brown, Glenn Sueyosh1, Robert Topel, and Stephen Trejo for useful comments, and to the National Sclence Foundation (Grant No. SES. 8809281) and the Russell Sage Foundation for financial support.

1. See Gordon (1964) for a presentation of the assimilation hypothesis.

2. See, for example, Borjas (1985, 1987, 1990a), Chiswick (1978), Jasso and Rosenzweig (1986).

3. Goldberger (1989) presents a critical appraisal of these models. Additional theoretical studies of intergenerational mobility include Conlisk (1974), Loury (1981).

4. See Atkinson (1981), Behrman and Taubman (1985), and Hauser, Sewell, and Lutterman (1975).

5. A number of generalizations of the model are possible. For instance, it is easy to allow for variable migration costs. The key results unaffected as long as the correlation between migration costs and earnings is not "excessive." Second, alternative host countries can be introduced. Individuals would then compare the gains from migrating to the United States with the gains from migrating to other countries. Under some simplifying assumptions, this model generates a sorting where there is a positive correlation between the average skills of persons choosing a particular country and the rate of returns to skills in that country. Finally, the model can be expanded to allow for remigration. Such remigration arises when potential migrants are uncertain about earnings opportunities in the United states, and actual economic conditions here are inferior to those 
avallable in the source country. It can be shown that return migration increases the intensity of the selection process. In particular, it is the "marginal" 1mmigrants who are most likely to return to the source country.

6. Applications of the dynastic approach Include Becker (1974) and Becker and Barro (1989).

7. The 1940 and 1950 Censuses report some of the key variables only for the "sample l1ne" respondents. In the 1970 Census, a 1/100 random sample is used for the third generation. Otherwise, all avallable observations are used in the study, subject to the qualification that they satisfy the sample restrictions and that valid data are reported.

8. This sample selection introduces biases into the analysis, but the Inclusion of non-workers or of the self-employed would require the use of non-robust selectivity-correction techniques, or the adjustment of selfemployment Incomes to make them comparable to salaried wage.

9. These data are obtained from the respondent's answer to the question of where he was residing five years prior to the Census. If the respondent is foreign-born, and if he resided abroad at that time, I assume that he migrated to the United States in the flve-year perlod. These data are not avallable for the 1950 Census.

10. Note that these intercensal comparisons are contaminated by period effects. The discussion implicitly assume that period effects (1,e., the Impact of business cycle fluctuations on the log wage) are the same for first, second, and third generation workers, so that relative wages are Invariant over the cycle. Little is known, however, about the sensitivity of the earnings of various ethnic groups to business cycle fluctuations.

11. The typical immigrant enumerated in the 1940 Census obtained his 
schooling in a western European country, while the typical immigrant in 1970 probably obtained his schooling in Latin American or Asia. The content and transferability of schooling obviously differs across countries. The secular trend in the standardized wage differentials between second generation workers and Immigrants reported in Table 1 Ignores differences in schooling quality across immigrant cohorts.

12. For instance, if most children are born while their parents are in their 20s, men aged 45-64 in 1940 would have children aged 15-44 at that time. By 1970, these children would be aged 45-74. In the empirical analysis, I experimented with alternative age groups, as well as with using the Iimfted year-of-migration data avallable in the 1940 Census to better match parents and children. These additional specifications led to essentially identical results.

13. It would be of interest to determine if the extent of Intergenerational mobility depends on whether both parents are foreign-born, and If so, on whether both parents have the same national origin. I have not pursued these questions in this paper.

14. The regressions are estimated using generalized least squares to account for the fact that the dependent variable is only an estimate of the true variable. The correction had little impact on the estimated parameters or standard errors.

15. My estimate of $\delta$ is at the higher end of the range usually reported in the literature. Becker and Tomes (1986) survey the avallable estimates and find that they range between .2 and, 4 . The higher value presented in this paper is partly due to the aggregation within national origin groups, This aggregation probably reduces the amount of measurement error (Solon, 
1990). Moreover, even in the absence of measurement error, the estimates from the aggregate regression and the typical individual-level regression will differ. It is well known (Lewis, 1986, p.24) that the aggregate regression estimates parameters from the micro regression model:

$$
y_{i j}(2)-\alpha+\beta_{1} y_{i j}(1)+\beta_{2} \bar{y}_{j}(1)+\epsilon_{i}
$$

where $y_{1 j}(2)$ represents the earnings of second-generation person $i$ in ethnic group $j ; y_{i j}(1)$ represents the earnings of his father; and $\bar{y}_{j}(1)$ gives the mean earnings of the father's ethnic group. Hence the expected earnings of people who have similarly-skilled parents, but who come from ethnic groups with different average skills will differ. In effect, (FI) provides a particular specification for an ethnic-group fixed effect in earnings (see Borfas, 1992, for a more detailed discussion of this model). Equation (9) can be derived from (FI) by aggregating within ethnic groups. The estimate of $\delta$ in Census data, therefore, is the sum of coefficients $\beta_{1}+\beta_{2}$ (in an appropriately weighted regression). Note that the predicted earnings of the son of the average father in any ethnic group depends on the sum $\beta_{1}+\beta_{2}$.

16. These data, with the exception of the English language variable. are discussed in detall in Borjas (1987). The English language varlable is obtained from Paxton (1988).

17. The regressions were also estimated for other Census years, as well as on a pooled data set. The 1970 estimates are representative of the set of results obtained from these alternative speciflcations.

18. The per-capita GNP variable plays two roles in the analysis. First, it is likely that the skills of immlgrants originating in higher per- 
capita GNP countries are more easily transferable to the U.S. labor market, generating a positive correlation between Immigrant earnings and per-capita Incomes in the source country. In addition, changes in both per-capita GNP and distance alter the size of the Immigrant flow and affect the intensity of the selection process. This theoretical Insight 1 s discussed below. 


\section{REFERENCES}

Atkinson, Anthony B. "On Intergenerational Income Mobility in Britain," Journal of Post Keynesian Economics 3 (Winter 1980-1981): 194-217.

Becker, Gary S. "A Theory of Social Interactions," Journal of Political Economy 82 (December 1974): 1063-1093.

- Treatise on the Family. Cambridge, Mass.: Harvard University Press, 1981.

Becker, Gary S, and Robert J. Barro. "A Reformulation of the Economic Theory of Fertility," Quarterly Journal of Economics 103 (February 1988): $1-25$.

Becker, Gary S, and Nigel Tomes. "Buman Capital and the Rise and Fall of Families," Journal of Labor Economics 4 (July 1986): S1-S39.

Behrman, Jere and Paul Taubman. "Intergenerational Earnings and Mobility in the United States: Some Estimates and a Test of Becker's Intergenerational Endowments Mode1," Review of Economics and Statistics 67 (February 1985): 144-151.

Borjas, George J. "Assimilation, Changes in Cohort Quality, and the Earnings of Imigrants," Journal of Labor Economics 3 (October 1985): $463-489$.

. "Self-Selection and the Earnings of Immigrants," American Economic Review 77 (September 1987): 531.553.

\section{Efiends or Strangers: The Impact of Immigrants on the} U.S. Economy. New York: Basic Books, 1990.

"Ethnic Capital and Intergenerational Mobility," Quarterly Journal of Economics 107 (February 1992): in press.

Carliner, Geoffrey. "Wages, Earnings, and Hours of First, Second and Third Generation American Males," Economic Inquiry 18 (January 1980): 87-102.

Chiswick, Barry R. "Sons of Immigrants: Are They at an Earnings Disadvantage?" American Economic Review. Papers and Proceeding 67 (February 1977): 376.774 .

"The Effect of Americanization on the Earnings of Foreign-Born Men, " Journal of Political Economy 86 (October 1978): 897-921.

Conlisk, John. "Can Equalization of Opportunity Reduce Soclal Mobility?" American Economic Review 64 (March 1974): 80-90. 
Glazer, Nathan and Daniel P. Moynihan. Beyond the Melting Pot: The Negroes. Puerto Ricans, Jews, Italians, and Irish of New York C1cy. Cambridge, Mass.: M.I.T. Press, 1963.

Goldberger, Arthur. "Economic and Mechanical Models of Intergenerational Transmission," American Economic Review 79 (June 1989): 504-513.

Gordon, Milton. Assimilation and American Life. New York: Oxford University Press, 1964.

Hauser, Robert M., Sewell, William H. and Kenneth G. Lutterman. "Soc1oEconomlc Background, Abllity, and Achlevement." In Education. Occupation, and Earnings, edited by William H. Sewell and Robert M. Hauser. New York: Academic Press, 1975.

Jasso, Guillermina and Mark R. Rosenzweig. "What's in a Name? Country of Origin Influences on the Earnings of Imbigrants in the United States," Research in Human Capital and Development 4 (1986): 75-106.

Lewis, H. Gregg. Union Relative Wage Effects: A Survey, Chicago: University of Chicago Press, 1986.

Lipset, Seymour Martin and Reinhard Bendix. Social Mobilicy in Industrial Soclety. Berkeley and Los Angeles: University of California Press, 1959.

Loury, Glenn C. "Intergenerational Transfers and the Distribution of Earnings," Econometrica 49 (July 1981): 843.867.

Mincer, Jacob. "Investment in Human Capital and Personal Income Distribution," Journal of Political Economy 66 (August 1958): 281-302.

Paxton, John, editor. The Statesman's Yearbook, 125th Edition. New York: St. Martin's Press, 1988.

Roy, Andrew D. "Some Thoughts on the Distribution of Earnings," Oxford Economic Papers 3 (June 1951): 135-146.

Solon, Gary. "Intergenerational Income Mobility in the United States," Mimeograph, University of Michigan, 1990.

U.S. Immigration and Naturalization Service. Statistical Yearbook of the Innigration and Naturalization Service, 1988. Washington, D.C.:

U.S. Government Printing office, 1989. 